\title{
REPEATED APPLICATION OF FUEL REDUCTION TREATMENTS IN THE SOUTHERN APPALACHIAN MOUNTAINS, USA: IMPLICATIONS FOR ACHIEVING MANAGEMENT GOALS
}

\author{
Thomas A. Waldrop ${ }^{\text {* }}$, Donald L. Hagan², and Dean M. Simon ${ }^{3}$ \\ ${ }^{1}$ USDA Forest Service, Southern Research Station, \\ 233 Lehotsky Hall, Clemson, South Carolina 29634-0331, USA \\ ${ }^{2}$ Clemson University, Department of Forestry and Environmental Conservation, \\ 212 Lehotsky Hall, Clemson, South Carolina 29634-0331, USA \\ ${ }^{3}$ North Carolina Wildlife Resources Commission, \\ 8676 Will Hudson Road, Lawndale, North Carolina 28090, USA \\ *Corresponding author: Tel.: +1-864-656-5054, e-mail: twaldrop@fs.fed.us \\ ABSTRACT
}

\begin{abstract}
Fire and resource managers of the southern Appalachian Mountains, USA, have many questions about the use of prescribed fire and mechanical treatments to meet various land management objectives. Three common objectives include restoration to an open woodland, oak regeneration, and fuel reduction. This paper provides information about reaching each of these three management objectives by using prescribed burning (B), mechanical fuel reduction $(\mathrm{M})$, and a combination of both fire and mechanical treatment (MB). The southern Appalachian site of the National Fire and Fire Surrogate study has been burned three times and a mechanical treatment has been conducted twice since 2002. Stand structure was changed by each active treatment but restoration to an open woodland was not achieved by any. The MB treatment units developed the desired overstory structure but heavy sprouting of woody species in the understory prevented
\end{abstract}

El fuego y los gestores de recursos en el sur de las Montañas Apalaches, EEUU, tienen muchos interrogantes sobre la utilización de fuegos prescriptos y tratamientos mecánicos para lograr varios objetivos de manejo del recurso. Tres objetivos comunes incluyen la restauración en un arbustal abierto, la regeneración de roble, y la reducción del combustible. Este trabajo provee información para poder alcanzar cada uno de estos tres objetivos de manejo mediante el uso de quemas prescriptas (B), la reducción mecánica del combustible (M), y una combinación de ambos tratamientos de quemas y reducción mecánica del combustible (MB). El sitio del estudio del sur de las Montañas Apalaches perteneciente al National Fire y Fire Surrogate ha sido quemado tres veces y el tratamiento mecánico ha sido conducido dos veces desde 2002. La estructura del rodal fue cambiada por cada uno de los tratamientos activos, pero la restauración hacia un arbustal abierto no fue logrado por ninguno de ellos. Las unidades de tratamiento MB desarrollaron la estructura deseada el dosel superior, pero un fuerte rebrote de especies leñosas en el sotobosque impidieron el establecimiento de un suelo 
the establishment of a diverse herbaceous forest floor. Oak reproduction was increased by all active treatments, largely by sprouting of top-killed stems. The degree of fuel reduction differed by treatment. All treatments reduced the shrub layer, thus reducing the vertical fuel component. The $\mathrm{B}$ and $\mathrm{MB}$ treatments reduced most fuels and likely reduced the severity of a subsequent wildfire. We conclude that additional burning is required to meet each management objective, and that fires should be conducted more frequently, in different seasons, or in combination with other treatments. forestal herbáceo y diverso. La reproducción del roble se incrementó en todos los tratamiento activos, la mayoría por el rebrote del ápice muerto de los fustes. El grado de reducción del combustible difirió en cada uno de los tratamientos. Todos los tratamientos redujeron la capa de arbustos, disminuyendo por lo tanto el componente vertical del combustible. Los tratamientos B y MB redujeron la mayoría de los combustibles y probablemente la severidad de un incendio posterior. Nosotros concluimos que quemas adicionales son requeridas para alcanzar cada uno de los objetivos de manejo, y que estos fuegos deberían ser realizados más frecuentemente, en diferentes temporadas, o en combinación con otros tratamientos.

Keywords: fuel reduction, mechanical fuel reduction, oak regeneration, open woodland, prescribed fire, restoration

Citation: Waldrop, T.A., D.L. Hagan, and D.M. Simon. 2016. Repeated application of fuel reduction treatments in the southern Appalachian Mountains: implications for achieving management goals. Fire Ecology12(2): 28-47. doi: 10.4996/fireecology.1202028

\section{INTRODUCTION}

Forests of the southern Appalachian Mountains are among the most biologically diverse and complex in the United States, making them among the most difficult to manage. The Appalachian Plateau, Ridge and Valley Province, and the Blue Ridge Mountains cover over 32 million ha, including portions of North Carolina, South Carolina, Tennessee, Georgia, Alabama, Virginia, and Kentucky. The region has high ecosystem diversity because of its wide variety of land types, soils, precipitation levels, and disturbance histories (SAMAB 1996). Appalachian hardwood ecosystems were developed by a broad array of natural disturbances, but the role played by natural and anthropogenic fire has not been appreciated until recent years (Brose et al. 2001, Waldrop et al. 2007). In some areas, prescribed burning is not possible, such as along the wildland-urban interface. Mechanical treatments may prove to be an acceptable surrogate for fire, but little information is available.

Excessive fuel loading has become a concern in most forest types throughout the United States, particularly where wildfires were historically frequent. Contemporary ecosystems are highly altered from their historical conditions due to fire exclusion over the past century (Stanturf et al. 2002). As a result, forests with continuous canopies and sub-canopies developed over previously open grasslands, savannas, and woodlands (Buckner 1983, Dobyns 1983, Denevan 1992, MacCleery 1993, Pyne 1997). Fuel reduction in the southern Appalachian Mountains is challenging because of steep slopes, heavy fuels in some areas created by a lack of fire, and dense ericaceous shrubs (Waldrop et al. 2007). Lightning- and human-caused fires once played a significant role in determining the species composition and structure of southern Appalachian forests (Delcourt and Delcourt 
1997). However, federal and state fire exclusion policies, which began in the early twentieth century, likely reduced plant and community diversity and may have altered fuels (Brose et al. 2002). Prior to fire exclusion, hardwood ecosystems of the region had open canopies, few shrubs, and rich forest floor vegetation (Van Lear and Waldrop 1989), and oak species (Quercus spp. L.) were more common in regeneration than other tree species because of frequent fire (Brose and Van Lear 1998). In the absence of fire, the increase in forest density and structure resulting from succession of pine (Pinus spp. L.)-hardwood woodlands to hardwood-dominated forests, with concomitant ingrowth of flammable understory species such as mountain laurel (Kalmia latifolia L.) and rhododendron (Rhododendron spp. L.) cause increased concern for wildfire risk and potential damage from severe fires. Wildfires are a particular concern in the southern Appalachian Mountains because of an ongoing increase in the number of houses and retirement communities (SAMAB 1996).

Managers of the southern Appalachian Mountain region have only recently begun to establish guidelines for prescribed burning and mechanical fuel reduction. Much remains to be learned about treatment impacts across a landscape that is so complex as to have extremely dry and extremely wet sites within close proximity. A survey of managers in 2014 and 2015 indicated that priority knowledge gaps included the number of treatments needed to reach local restoration goals; impacts on threatened, endangered, and sensitive wildlife; impacts on oak reproduction; impacts of burning at different seasons; and how well treatments reduce fuels (S. Rodriguez, Clemson University, Clemson, South Carolina, USA, unpublished report). Although these are fundamental questions, they remain unanswered for the southern Appalachians because of the relatively new use of prescribed fire and mechanical fuel reduction in the region (Van Lear and Waldrop 1989).
In 2000, a team of federal, state, university, and private scientists and land managers designed the Fire and Fire Surrogate (FFS) study, an integrated national network to address the need for many types of information. The national network included 12 sites on federal and state lands extending from Washington to Florida. At each site, impacts of fuel reduction treatments were studied on a broad array of variables, including flora, fauna, fuels, soils, forest health, and economics (see Youngblood et al. 2005 for a description of the national study). Treatments were designed to restore ecosystems by re-establishing an ecosystem process (fire), stand structure (mechanical fuel reduction), or both. Changes in stand structure can alter ecosystem components such as vegetative diversity (Hutchinson 2006), fire behavior and return interval (Phillips et al. 2006, Waldrop et al. 2010), and soil processes (Boerner et al. 2008). McIver et al. (2012a, $2012 b$ ) summarized the national study by stating that treatments significantly modified stand structure and fuels, making post-treatment stands much more resistant to moderate wildfire. However, for the great majority of ecosystem components, short-term response to treatments were subtle and, over time, ecosystem effects dampened and fire risk increased.

Most FFS sites were abandoned after reporting impacts that occurred within one year after treatment. However, managers at the FFS site in the southern Appalachian Mountains have been able to continue the prescribed burning and mechanical treatments for over 13 years. The primary objective of the managers of the Appalachian site is to reduce wildfire severity by reducing live and dead fuels. Their secondary objectives are to increase oak reproduction and to improve wildlife habitat by increasing cover of grasses and forbs. It may be possible to obtain each of these goals by restoring this community to the open woodland habitat (described in syntheses by Stanturf et al. 2002 and Van Lear and Waldrop 1989). Numerous variables measured in the first year 
of the Appalachian FFS study strongly indicated that repeated entries of fire or mechanical treatments or both were necessary to reach these objectives. If the fuel-reduction treatments on the Appalachian FFS site can meet manager objectives over time, they will provide much of the information identified as top knowledge gaps by managers. Here, we examine each fuel-reduction treatment in the context of those top knowledge gaps: restoration to an open woodland community, oak regeneration, and fuel reduction. Changes to vegetation, stand structure, and fuels over time are discussed for each active treatment as they occurred over three prescribed burns and two mechanical fuel-reduction treatments.

\section{METHODS}

The study site is located in Polk County, North Carolina, on the Green River Game Land, which is managed for wildlife habitat, timber, and other resources by the North Carolina Wildlife Resources Commission. Elevations range from $350 \mathrm{~m}$ to $750 \mathrm{~m}$. Forests of the study area were $80 \mathrm{yr}$ to $120 \mathrm{yr}$ old and showed no indication of past agriculture or recent fire. Forest composition was mixed-oak (Quercus spp.) with pitch pine (Pinus rigida Mill.) and Table Mountain pine (P. pungens Lamb.) on xeric ridges and eastern white pine (P. strobus L.) in moist coves. A dense layer of ericaceous shrubs - mostly mountain laurel (Kalmia latifolia L.) and rhododendron (Rhododendron maximum L.) — was found throughout. Soils were primarily of the Evard series (fine loamy, oxidic, mesic Typic Hapludults). These were moderately deep, well-drained, mountain upland soils (Keenan 1998).

The experiment was designed as a randomized complete block with three replicate blocks composed of four factorial treatment units. Individual treatment units were 10 ha to 12 ha in size. All treatment units were surrounded by buffer zones of approximately 4 ha, and both the treatment unit and its corresponding buffer received the experimental treatment. These treatment units were designed to include all prevailing combinations of elevation, aspect, and slope. However, these conditions varied within experimental units (treatment units) and were not separated for analysis. Differences in site quality among and within treatment units probably impacted study results. A $50 \mathrm{~m} \times 50$ $\mathrm{m}$ grid was established in each treatment unit to measure fuels. Grid points were permanently marked and georeferenced. Ten sample plots of 0.1 ha each were established at randomly selected grid points within each treatment unit to measure vegetation.

Treatments were designed to reduce fuels, increase the density of oak reproduction, and improve habitat for some wildlife species by producing open woodlands. Our definition of woodlands was given by Kabrick et al. (2014), who described them as "natural communities characterized by open to nearly closed canopies of overstory trees, relatively sparse midstory and understory, and dense, species-rich ground flora." In contrast to forests, many of the dominant and codominant trees in the canopy of woodlands have large, spreading crowns (Nuzzo 1986, Nelson 2005, Taft 2009). Shrubs, saplings, and small trees may be present but generally are much less abundant than in a mature forest (Nelson 2005). The relatively open canopy and midstory of woodlands allows sunlight to reach the ground to support a species-rich layer of light-demanding plants dominated by forbs, sedges, and grasses that may be present but seldom are abundant in closed-canopy forests (Kinkead et al. 2013).

Factorial treatments were randomly allocated among treatment units within a site, and all treatment units were sampled through the pretreatment year (2001). Factors included prescribed burning (with and without) and mechanical treatment (with and without). These combinations allowed results in four treatments: an untreated control (C), prescribed burning (B), mechanical fuel reduction (M), and a combination of mechanical treatment 
and prescribed burning (MB). The $\mathrm{M}$ treatment involved creating a vertical fuel break by chainsaw felling all tree stems $>1.8 \mathrm{~m}$ tall and $<10 \mathrm{~cm}$ diameter at breast height (dbh), and all shrubs regardless of size. This treatment was accomplished by a contract crew between December 2001 and February 2002. A second chainsaw felling of small trees and shrubs was completed in early 2012 (January to February) in $\mathrm{M}$ units only. A second mechanical treatment was not required in $\mathrm{MB}$ treatment units. Prescribed fires were applied in B and MB units during March 2003, 2006, and 2012. The objectives of prescribed burning were to remove the shrub layer and create a few snags for habitat. All fires were burned with a spotfire technique; the first was done by helicopter ignition and the others were done by hand ignition. During the first fire, flame lengths of 1 $\mathrm{m}$ to $2 \mathrm{~m}$ occurred throughout all burn units but reached up to $5 \mathrm{~m}$ in localized areas. Loads of fine woody fuels in MB sites were essentially double that of burn-only sites due to the felling of the shrub layer. Temperatures measured with thermocouples placed $30 \mathrm{~cm}$ (12 in) above ground averaged $180^{\circ} \mathrm{C}\left(356^{\circ} \mathrm{F}\right)$ during 2003 and $155^{\circ} \mathrm{C}\left(311^{\circ} \mathrm{F}\right)$ during 2006 in burn-only sites. Fires in MB sites were considerably hotter with mean temperatures of $370^{\circ} \mathrm{C}\left(698^{\circ} \mathrm{F}\right)$ in 2003 and $222^{\circ} \mathrm{C}\left(432^{\circ} \mathrm{F}\right)$ in 2006. Thermocouple readings were not possible for the third fire, but flame lengths were observed to be $0.5 \mathrm{~m}$ to $1.5 \mathrm{~m}$ in $\mathrm{B}$ units and 1 $\mathrm{m}$ to $2 \mathrm{~m}$ in $\mathrm{MB}$ units.

Vegetation and fuels data were collected before treatment (2001) and at various years after treatment, depending on the date the treatment was completed. All measurements were made during the growing season. We measured B plots in 2003 (one growing season after burning); 2005 (three growing seasons after burning); 2006 (one growing season after the second burn); 2011 (one growing season before the third burn); and 2012, 2013, and 2014 (one, two, and three growing seasons after the third burn, respectively). We measured
$\mathrm{M}$ plots in 2002 (one growing season after felling); 2004 (three growing seasons after felling); 2006 (five growing seasons after felling); 2011 (one growing season before the second felling); and 2012, 2013, and 2014 (one, two and three growing seasons after the second felling, respectively). The MB plots were measured in 2002 (one growing season after felling); 2003 (one growing season after burning); 2005 (three growing seasons after burning); 2006 (one growing season after the second burn); 2011 (one growing season before the third burn); and 2012, 2013, and 2014 (one, two, and three growing seasons after the third burn, respectively). We measured C plots every year from 2001 through 2006 and annually from 2011 through 2014.

Vegetation data were collected on the 0.1 ha sample plots. Each plot was $50 \mathrm{~m} \times 20 \mathrm{~m}$ and divided into 10 subplots, each $10 \mathrm{~m} \times 10$ m. All trees $\geq 10 \mathrm{~cm}$ dbh were measured in five subplots at each sample date. For each tree, the tree number, species, dbh, and status (i.e., standing live or dead) were recorded. Vegetation in the shrub layer was measured on five $10 \mathrm{~m} \times 10 \mathrm{~m}$ subplots. This layer consisted of saplings (trees $>1.4 \mathrm{~m}$ tall and $<10 \mathrm{~cm}$ $\mathrm{dbh}$ ) and shrubs. Saplings were recorded by species, status, and dbh class. Status included live (unaffected by treatment), top-killed (aboveground stem dead but sprouts present), dead, or harvested. Diameter at breast height classes included $<3 \mathrm{~cm}, 3 \mathrm{~cm}$ to $6 \mathrm{~cm}$, and $>6 \mathrm{~cm}$ to $10 \mathrm{~cm}$. Stems within a sprout clump were counted separately. Ocular estimates of the percentage of area covered by the crowns of each shrub species, of any height over $1.4 \mathrm{~m}$, were also recorded within five subplots. Sapling and shrub data were combined into broad species groups for analysis. Dominant species or species of special interest were selected, which included all oaks, mountain laurel, and rhododendron. Mean percent cover values were evaluated for each species or species group. A total of $201 \mathrm{~m}^{2}$ quadrats was established in each vegetation sample plot to mea- 
sure forest floor cover $(<1.4 \mathrm{~m}$ tall). Quadrats were located at the upper-right and lower-left corner of each $10 \mathrm{~m} \times 10 \mathrm{~m}$ subplot, as viewed from the downslope subplot edge. Trees, shrubs, and all herbaceous species were recorded by species and cover class. Cover classes included $<1 \%, 1 \%$ to $10 \%,>10 \%$ to $25 \%,>25 \%$ to $50 \%,>50 \%$ to $75 \%$, and $>75 \%$. Data from all species in the groundcover vegetation were summarized into general life form categories (forbs, grasses, shrubs, and trees) using mean percent cover values for each plot.

Down dead woody fuels were measured before and after treatment using the planar intercept method described by Brown (1974). Three $15.2 \mathrm{~m}$ transects were established approximately $2 \mathrm{~m}$ from each grid point in a randomly selected direction. This method produced a total of over $21000 \mathrm{~m}$ of fuel transects. Litter depth and duff depth were measured at three locations along each fuel transect at 3.0 $\mathrm{m}, 7.6 \mathrm{~m}$, and $12.2 \mathrm{~m}$ from the origin.

Analysis of treatment effects on vegetation and fuels was conducted using ANOVA for each combination of year and variable, with treatment modeled as a fixed effect and block as a random effect. Treatment differences within a year were considered significant with an overall experimental $\alpha$ of 0.05 . However, the large number of years tested increased the probability of a Type I error, so we used the Bonferroni correction (Bland and Altman $1995)$ to adjust test statistics. Individual tests for each year were done at $\alpha=0.00625$. We made post hoc comparisons using linear contrasts. Because much of the data did not meet the assumption of normality, it was necessary to use data transformations to normalize the distributions. Logarithmic and square root transformations were used in these analyses.

\section{RESULTS}

Changes to vegetation and fuels over time are presented for each active treatment individually to focus on how each treatment af- fected manager objectives including restoration, oak regeneration, and fuel reduction.

\section{Mechanical Treatment (M)}

Chainsaw felling of small trees and shrubs had essentially no impact on the basal area and density of overstory trees $(>10 \mathrm{~cm} \mathrm{dbh})$ at any time during the study. Basal area gradually increased from $27.3 \mathrm{~m}^{2} \mathrm{ha}^{-1}$ prior to treatment, to $30.3 \mathrm{~m}^{2} \mathrm{ha}^{-1}$ by the twelfth growing season after treatment (Table 1). There were no significant differences in basal area between $\mathrm{C}$ treatment units (Figure 1) and $\mathrm{M}$ units (Figure 2) at any time. Overstory stem density decreased over time in $\mathrm{M}$ units from 642 stems ha $^{-1}$ prior

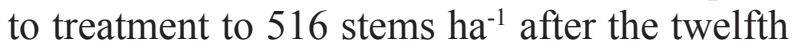
growing season after treatment (Table 1). There were no significant differences in stem density between $\mathrm{M}$ and $\mathrm{C}$ units at any time.

The most dramatic impact of the $M$ treatment was the reduction of density and cover in the shrub layer $(>1.4 \mathrm{~m}$ tall and $\leq 10 \mathrm{~cm} \mathrm{dbh})$. Stems of the shrub layer numbered $1433 \mathrm{ha}^{-1}$ prior to cutting with $76.8 \%$ cover (Table 2 ). These values were not significantly different from those of $\mathrm{C}$ treatment units prior to treatment. One year after treatment, stems of the shrub layer reduced in number and cover to $447 \mathrm{ha}^{-1}$ and $8.0 \%$, respectively. These values were significantly lower than those in $\mathrm{C}$ units. Density and cover of this size class increased over time until there were no significant differences between these variables in $\mathrm{M}$ and $\mathrm{C}$ treatment units by year 9 . The second mechanical treatment occurred in year 10 , causing stem numbers and density to be significantly lower in $\mathrm{M}$ than in $\mathrm{C}$ units that year. By year 12, density of stems in the shrub layer had increased and it was not different than density in $\mathrm{C}$ units. However, shrub layer cover was still much lower in $\mathrm{M}$ than in $\mathrm{C}$ units.

The number of tree stems (all species combined) in the regeneration layer $(\leq 1.4 \mathrm{~m}$ tall) did not differ between $\mathrm{M}$ and $\mathrm{C}$ treatment units at any time except year 12 when stems in $\mathrm{M}$ units numbered 37816 ha $^{-1}$ while those in $\mathrm{C}$ 
Table 1. Mean overstory ( $>10 \mathrm{~cm} \mathrm{dbh})$ basal area and stem density by treatment and year, Green River Game Land, Polk County, North Carolina, USA.

\begin{tabular}{|c|c|c|}
\hline & $\begin{array}{c}\text { Basal area } \\
\left(\mathrm{m}^{2} \mathrm{ha}^{-1}\right)\end{array}$ & $\begin{array}{c}\text { Density } \\
\left(\text { stems ha }^{-1}\right)\end{array}$ \\
\hline \multicolumn{3}{|c|}{ Pretreatment } \\
\hline $\mathrm{C}$ & 26.5 & 641 \\
\hline B & 26.5 & 632 \\
\hline M & 27.3 & 642 \\
\hline MB & 23.8 & 574 \\
\hline
\end{tabular}

Year 1 (1 growing season after first burn and mechanical treatments)

\begin{tabular}{ccc} 
C & $27.0 \mathrm{~b}^{1}$ & 642 \\
$\mathrm{~B}$ & $26.3 \mathrm{~b}$ & 653 \\
$\mathrm{M}$ & $27.6 \mathrm{~b}$ & 646 \\
MB & $21.0 \mathrm{a}$ & 598 \\
\hline Year 3 & & \\
$\mathrm{C}$ & $28.1 \mathrm{~b}$ & $608 \mathrm{~b}$ \\
$\mathrm{~B}$ & $26.1 \mathrm{~b}$ & $581 \mathrm{~b}$ \\
M & $28.8 \mathrm{~b}$ & $643 \mathrm{~b}$ \\
MB & $18.3 \mathrm{a}$ & $456 \mathrm{a}$ \\
\hline Year 5 (1 growing season after second burn) \\
C & $27.6 \mathrm{~b}$ & $593 \mathrm{~b}$ \\
B & $25.9 \mathrm{~b}$ & $562 \mathrm{~b}$ \\
M & $29.0 \mathrm{~b}$ & $629 \mathrm{~b}$ \\
MB & $16.5 \mathrm{a}$ & $406 \mathrm{a}$ \\
\hline Year 9 & & \\
C & $28.8 \mathrm{c}$ & $561 \mathrm{c}$ \\
B & $24.5 \mathrm{~b}$ & $482 \mathrm{~b}$ \\
M & $29.5 \mathrm{c}$ & $598 \mathrm{c}$ \\
MB & $14.6 \mathrm{a}$ & $306 \mathrm{a}$ \\
\hline
\end{tabular}

Year 10 (1 growing season after third burn and second mechanical treatments)

\begin{tabular}{ccc} 
C & $29.4 \mathrm{c}$ & $533 \mathrm{c}$ \\
$\mathrm{B}$ & $24.9 \mathrm{~b}$ & $407 \mathrm{~b}$ \\
$\mathrm{M}$ & $29.6 \mathrm{c}$ & $511 \mathrm{c}$ \\
$\mathrm{MB}$ & $14.6 \mathrm{a}$ & $165 \mathrm{a}$ \\
\hline Year 11 & & \\
$\mathrm{C}$ & $29.9 \mathrm{c}$ & $552 \mathrm{c}$ \\
$\mathrm{B}$ & $25.1 \mathrm{~b}$ & $400 \mathrm{~b}$ \\
$\mathrm{M}$ & $29.8 \mathrm{c}$ & $510 \mathrm{c}$ \\
MB & $14.6 \mathrm{a}$ & $163 \mathrm{a}$ \\
\hline Year 12 & & \\
C & $30.4 \mathrm{c}$ & $556 \mathrm{c}$ \\
$\mathrm{B}$ & $25.2 \mathrm{~b}$ & $401 \mathrm{~b}$ \\
M & $30.3 \mathrm{c}$ & $516 \mathrm{c}$ \\
MB & $14.9 \mathrm{a}$ & $165 \mathrm{a}$ \\
\hline
\end{tabular}

${ }^{1}$ Means followed by the same letter within a column and year are not significantly different at the Bonferroni adjusted level $\alpha=0.00625$ (overall $\alpha=0.05$ ). The absence of letters indicates that there were no significant differences within that column and year.

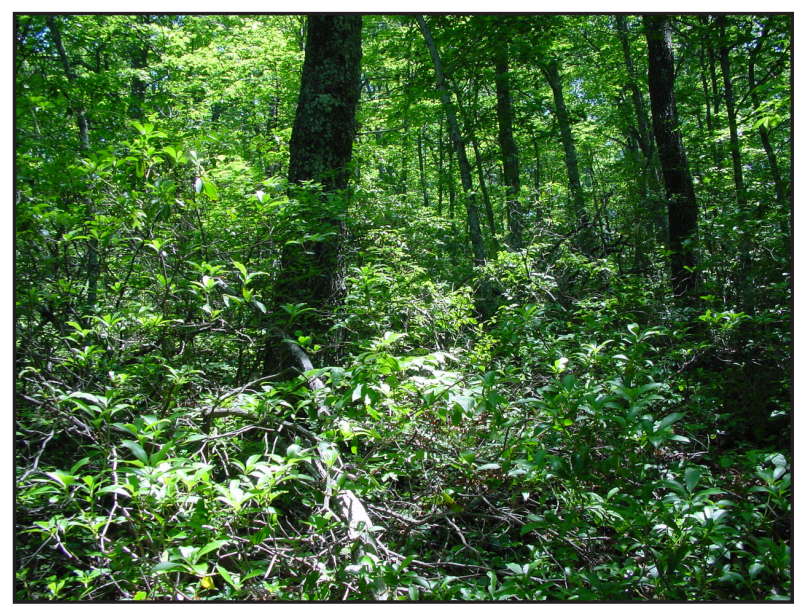

Figure 1. Untreated control units at the Appalachian Fire and Fire Surrogate study site can be thick with understory trees and shrubs.

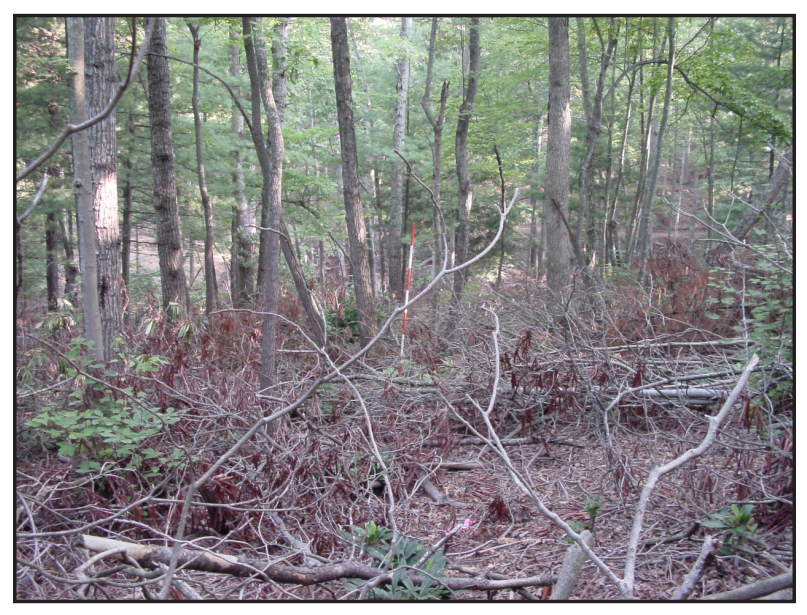

Figure 2. The mechanical-only treatment consisted of chainsaw felling of small trees and shrubs, which greatly increased loading of fine woody fuels and had little effect on overstory cover.

units numbered $26167 \mathrm{ha}^{-1}$ (Table 3). Even though stems cut by the $M$ treatment resprouted, sprout numbers were not sufficient to significantly increase numbers of stems in this category, other than during the third year after the second $\mathrm{M}$ treatment. Oak reproduction followed the same pattern as did all species combined (Table 3 ). Oaks $\leq 1.4 \mathrm{~m}$ tall in $\mathrm{M}$ treatment units did not differ in density from those in $\mathrm{C}$ units except during the last year of the study. At that time, oaks numbered 16482 ha $^{-1}$ in $\mathrm{M}$ units and 10984 ha $^{-1}$ in $\mathrm{C}$ units. 
Table 2. Mean shrub layer $(>1.4 \mathrm{~m}$ tall and $\leq 10$ $\mathrm{cm} \mathrm{dbh}$ ) density and cover by treatment and year, Green River Game Land, Polk County, North Carolina, USA.

\begin{tabular}{ccc}
\hline & $\begin{array}{c}\text { Density } \\
\text { (stems ha }^{-1} \text { ) }\end{array}$ & $\begin{array}{c}\text { Cover } \\
(\%)\end{array}$ \\
\hline Pretreatment & & \\
C & 1863 & 66.5 \\
B & 1559 & 40.0 \\
M & 1433 & 76.8 \\
MB & 1596 & 49.7 \\
\hline
\end{tabular}

Year 1 (1 growing season after first burn and mechanical treatments)

\begin{tabular}{lcr} 
C & $1919 \mathrm{c}^{1}$ & $94.4 \mathrm{c}$ \\
$\mathrm{B}$ & $664 \mathrm{ab}$ & $39.1 \mathrm{~b}$ \\
$\mathrm{M}$ & $447 \mathrm{a}$ & $8.0 \mathrm{a}$ \\
$\mathrm{MB}$ & $758 \mathrm{~b}$ & $7.1 \mathrm{a}$ \\
\hline
\end{tabular}

Year 3

$\begin{array}{llr}\text { C } & 1983 \mathrm{~b} & 86.6 \mathrm{c} \\ \mathrm{B} & 1514 \mathrm{ab} & 20.5 \mathrm{~b} \\ \mathrm{M} & 1025 \mathrm{a} & 12.8 \mathrm{a} \\ \mathrm{MB} & 4246 \mathrm{c} & 7.2 \mathrm{a}\end{array}$

Year 5 (1 growing season after second burn)

\begin{tabular}{lrr}
$\mathrm{C}$ & $1717 \mathrm{~b}$ & $71.0 \mathrm{~b}$ \\
$\mathrm{~B}$ & $850 \mathrm{a}$ & $18.1 \mathrm{a}$ \\
$\mathrm{M}$ & $1210 \mathrm{a}$ & $22.1 \mathrm{a}$ \\
$\mathrm{MB}$ & $2435 \mathrm{c}$ & $2.3 \mathrm{a}$ \\
\hline
\end{tabular}

Year 9

$\begin{array}{lll}\text { C } & 2082 \mathrm{a} & 66.6 \\ \mathrm{~B} & 3376 \mathrm{~b} & 23.6 \\ \text { M } & 1902 \mathrm{a} & 42.3 \\ \text { MB } & 7781 \mathrm{c} & 35.4\end{array}$

Year 10 (1 growing season after third burn and second mechanical treatments)

\begin{tabular}{crr} 
C & $2018 \mathrm{c}$ & $73.1 \mathrm{~b}$ \\
$\mathrm{~B}$ & $309 \mathrm{a}$ & $8.7 \mathrm{a}$ \\
$\mathrm{M}$ & $284 \mathrm{a}$ & $6.5 \mathrm{a}$ \\
$\mathrm{MB}$ & $1077 \mathrm{~b}$ & $1.4 \mathrm{a}$ \\
\hline Year 11 & & \\
$\mathrm{C}$ & $2020 \mathrm{ab}$ & $72.9 \mathrm{~b}$ \\
$\mathrm{~B}$ & $2517 \mathrm{~b}$ & $13.3 \mathrm{a}$ \\
$\mathrm{M}$ & $716 \mathrm{a}$ & $6.2 \mathrm{a}$ \\
MB & $8588 \mathrm{c}$ & $18.4 \mathrm{a}$ \\
\hline Year 12 & & \\
$\mathrm{C}$ & $1991 \mathrm{ab}$ & $95.8 \mathrm{~b}$ \\
$\mathrm{~B}$ & $3300 \mathrm{~b}$ & $17.2 \mathrm{a}$ \\
M & $1042 \mathrm{a}$ & $10.0 \mathrm{a}$ \\
MB & $10169 \mathrm{c}$ & $30.7 \mathrm{a}$ \\
\hline
\end{tabular}

${ }^{1}$ Means followed by the same letter within a column and year are not significantly different at the Bonferroni adjusted level $\alpha=0.00625$ (overall $\alpha=0.05$ ). The absence of letters indicates that there were no significant differences within that column and year.
Table 3. Mean density of tree reproduction $(\leq 1.4$ $\mathrm{m}$ tall) for oaks and all species combined by treatment and year, Green River Game Land, Polk County, North Carolina, USA.

\begin{tabular}{ccc}
\hline & $\begin{array}{c}\text { Oaks } \\
\left(\text { stems ha }^{-1}\right)\end{array}$ & $\begin{array}{c}\text { All species } \\
\left(\text { stems ha }^{-1}\right)\end{array}$ \\
\hline Pretreatment & & \\
C & 13001 & 29450 \\
B & 13649 & 33666 \\
M & 12315 & 22166 \\
MB & 15801 & 29116 \\
\hline
\end{tabular}

Year 1 (1 growing season after first burn and mechanical treatments)

\begin{tabular}{lll} 
C & $11950 \mathrm{a}^{1}$ & $31648 \mathrm{a}$ \\
$\mathrm{B}$ & $15400 \mathrm{ab}$ & $83214 \mathrm{~b}$ \\
M & $11117 \mathrm{a}$ & $22331 \mathrm{a}$ \\
MB & $20116 \mathrm{~b}$ & $80468 \mathrm{~b}$ \\
\hline
\end{tabular}

Year 3

$\begin{array}{llr}\text { C } & 15484 \mathrm{a} & 45917 \mathrm{a} \\ \mathrm{B} & 30882 \mathrm{~b} & 129334 \mathrm{c} \\ \mathrm{M} & 11500 \mathrm{a} & 30949 \mathrm{a} \\ \text { MB } & 28850 \mathrm{~b} & 90968 \mathrm{~b}\end{array}$

Year 5 (1 growing season after second burn)

\begin{tabular}{ccc} 
C & $13701 \mathrm{a}$ & $36183 \mathrm{a}$ \\
$\mathrm{B}$ & $23134 \mathrm{bc}$ & $65332 \mathrm{~b}$ \\
$\mathrm{M}$ & $18117 \mathrm{ab}$ & $39982 \mathrm{a}$ \\
$\mathrm{MB}$ & $28417 \mathrm{c}$ & $69281 \mathrm{~b}$ \\
\hline Year 9 & & \\
$\mathrm{C}$ & 13098 & $29899 \mathrm{a}$ \\
$\mathrm{B}$ & 20333 & $54750 \mathrm{~b}$ \\
$\mathrm{M}$ & 14867 & $29751 \mathrm{a}$ \\
MB & 21099 & $47384 \mathrm{~b}$ \\
\hline
\end{tabular}

Year 10 (1 growing season after third burn and second mechanical treatments)

\begin{tabular}{ccc} 
C & $13484 \mathrm{a}$ & $32683 \mathrm{a}$ \\
$\mathrm{B}$ & $24893 \mathrm{~b}$ & $76652 \mathrm{~b}$ \\
$\mathrm{M}$ & $16868 \mathrm{a}$ & $30784 \mathrm{a}$ \\
MB & $38633 \mathrm{c}$ & $87517 \mathrm{~b}$ \\
\hline Year 11 & & \\
C & $13884 \mathrm{a}$ & $32699 \mathrm{a}$ \\
$\mathrm{B}$ & $25051 \mathrm{~b}$ & $79601 \mathrm{~b}$ \\
M & $16282 \mathrm{a}$ & $40051 \mathrm{a}$ \\
MB & $29751 \mathrm{~b}$ & $70516 \mathrm{~b}$ \\
\hline Year 12 & & \\
C & $10984 \mathrm{a}$ & $26167 \mathrm{a}$ \\
B & $21366 \mathrm{bc}$ & $69849 \mathrm{~d}$ \\
M & $16482 \mathrm{~b}$ & $37816 \mathrm{~b}$ \\
MB & $21499 \mathrm{c}$ & $50366 \mathrm{c}$ \\
\hline
\end{tabular}

${ }^{1}$ Means followed by the same letter within a column and year are not significantly different at the Bonferroni adjusted level $\alpha=0.00625$ (overall $\alpha=0.05$ ). The absence of letters indicates that there were no significant differences within that column and year. 
Cover of all forest floor plants ( $\leq 1.4 \mathrm{~m}$ tall) combined was not significantly different from $\mathrm{C}$ treatment units except during the third year after the second treatment (year 12; Table 4) when cover of all species of plants was signifi- cantly higher in $\mathrm{M}$ units than in $\mathrm{C}$ units. Cover of individual species groups (forbs, grasses, shrubs, and trees) was largely unaffected by the $\mathrm{M}$ treatment. Forbs had significantly lower cover during year 5 in $\mathrm{M}$ units than in $\mathrm{C}$ units.

Table 4. Mean percent forest floor $(<1.4 \mathrm{~m}$ tall) cover by species group, treatment, and year, Green River Game Land, Polk County, North Carolina, USA.

\begin{tabular}{|c|c|c|c|c|c|}
\hline & $\begin{array}{c}\begin{array}{c}\text { Forbs } \\
(\%)\end{array} \\
\text { (\%) }\end{array}$ & $\begin{array}{c}\text { Grass } \\
(\%)\end{array}$ & $\begin{array}{c}\text { Shrubs } \\
(\%)\end{array}$ & $\begin{array}{c}\text { Trees } \\
(\%)\end{array}$ & $\begin{array}{c}\text { Total } \\
(\%)\end{array}$ \\
\hline \multicolumn{6}{|c|}{ Pretreatment } \\
\hline $\mathrm{C}$ & 5.3 & 0.7 & 22.9 & 7.2 & 25.1 \\
\hline B & 5.4 & 0.2 & 9.2 & 6.2 & 21.0 \\
\hline M & 2.7 & 0.3 & 15.6 & 5.2 & 23.9 \\
\hline MB & 5.0 & 0.3 & 17.2 & 6.7 & 29.3 \\
\hline \multicolumn{6}{|c|}{ Year 1 (1 growing season after first burn and mechanical treatments) } \\
\hline $\mathrm{C}$ & 5.8 & 0.7 & 10.5 & 5.9 & 23.0 \\
\hline B & 3.4 & 0.5 & 3.5 & 6.2 & 13.5 \\
\hline $\mathrm{M}$ & 3.4 & 0.4 & 14.3 & 6.4 & 24.5 \\
\hline MB & 3.5 & 0.8 & 6.2 & 7.8 & 18.2 \\
\hline \multicolumn{6}{|l|}{ Year 3} \\
\hline $\mathrm{C}$ & 4.3 & 0.7 & 10.4 & $6.5 \mathrm{a}$ & 22.0 \\
\hline B & 3.2 & 0.7 & 7.9 & $9.6 \mathrm{a}$ & 21.4 \\
\hline M & 2.8 & 0.4 & 19.8 & $7.9 \mathrm{a}$ & 30.9 \\
\hline MB & 5.3 & 2.2 & 14.6 & $17.3 \mathrm{~b}$ & 39.4 \\
\hline \multicolumn{6}{|c|}{ Year 5 (1 growing season after second burn) } \\
\hline $\mathrm{C}$ & $3.5 \mathrm{~b}^{1}$ & 0.9 & 12.8 & $6.9 \mathrm{a}$ & 24.2 \\
\hline B & $3.3 \mathrm{~b}$ & 1.0 & 12.2 & $10.6 \mathrm{~b}$ & 27.1 \\
\hline M & $2.2 \mathrm{a}$ & 0.3 & 20.2 & $7.1 \mathrm{a}$ & 29.8 \\
\hline MB & $5.8 \mathrm{c}$ & 3.1 & 21.1 & $14.7 \mathrm{~b}$ & 44.6 \\
\hline \multicolumn{6}{|l|}{ Year 9} \\
\hline $\mathrm{C}$ & $3.6 \mathrm{ab}$ & 1.1 & 14.0 & 8.9 a & $27.6 \mathrm{a}$ \\
\hline B & $4.5 \mathrm{bc}$ & 1.1 & 15.1 & $16.2 \mathrm{~b}$ & $37.0 \mathrm{a}$ \\
\hline $\mathrm{M}$ & $2.3 \mathrm{a}$ & 0.4 & 22.0 & $9.9 \mathrm{a}$ & $34.6 \mathrm{a}$ \\
\hline MB & $6.6 \mathrm{c}$ & 2.4 & 26.1 & $19.0 \mathrm{~b}$ & $54.0 \mathrm{~b}$ \\
\hline \multicolumn{6}{|c|}{ Year 10 (1 growing season after third burn and second mechanical treatments) } \\
\hline $\mathrm{C}$ & 4.8 & 0.7 & 8.3 & $7.0 \mathrm{a}$ & $20.8 \mathrm{a}$ \\
\hline B & 5.1 & 0.2 & 5.3 & $11.2 \mathrm{a}$ & $21.8 \mathrm{a}$ \\
\hline M & 3.0 & 0.2 & 8.7 & $6.4 \mathrm{a}$ & $18.2 \mathrm{a}$ \\
\hline MB & 8.0 & 0.3 & 10.6 & $19.6 \mathrm{~b}$ & $38.5 \mathrm{~b}$ \\
\hline \multicolumn{6}{|l|}{ Year 11} \\
\hline $\mathrm{C}$ & $5.0 \mathrm{a}$ & 0.7 & 8.4 & $6.9 \mathrm{a}$ & $21.0 \mathrm{a}$ \\
\hline B & $7.0 \mathrm{a}$ & 0.2 & 9.7 & $13.1 \mathrm{~b}$ & $30.1 \mathrm{a}$ \\
\hline M & $3.8 \mathrm{a}$ & 0.1 & 14.8 & $9.8 \mathrm{ab}$ & $28.5 \mathrm{a}$ \\
\hline MB & $12.8 \mathrm{~b}$ & 0.5 & 18.7 & $21.6 \mathrm{c}$ & $53.5 \mathrm{~b}$ \\
\hline \multicolumn{6}{|l|}{ Year 12 } \\
\hline $\mathrm{C}$ & $4.8 \mathrm{a}$ & 0.7 & 10.4 & $6.2 \mathrm{a}$ & $22.1 \mathrm{a}$ \\
\hline B & $7.7 \mathrm{a}$ & 0.3 & 11.2 & $12.1 \mathrm{~b}$ & $31.4 \mathrm{ab}$ \\
\hline M & $4.8 \mathrm{a}$ & 0.1 & 19.7 & $10.8 \mathrm{~b}$ & $35.4 \mathrm{~b}$ \\
\hline MB & $13.0 \mathrm{~b}$ & 0.4 & 21.2 & $16.2 \mathrm{c}$ & $50.8 \mathrm{c}$ \\
\hline
\end{tabular}

${ }^{1}$ Means followed by the same letter within a column and year are not significantly different at the Bonferroni adjusted level $\alpha=0.00625$ (overall $\alpha=0.05$ ). The absence of letters indicates that there were no significant differences within that column and year. 
Tree cover was greater in $\mathrm{M}$ units than in $\mathrm{C}$ units during year 12 . There were no differences in forest floor cover between $\mathrm{M}$ units and $\mathrm{C}$ units for any other year or species group.

Mass of $1 \mathrm{hr}$ fuels and $100 \mathrm{hr}$ fuels, and depth of the litter layer were significantly higher the year after cutting small trees and shrubs in $\mathrm{M}$ treatment units than in $\mathrm{C}$ units (Table 5). By the third year after the first $M$ treatment, mass of all measured fuels was significantly greater in $\mathrm{M}$ units than in $\mathrm{C}$ units. During the fifth year after treatment, only 100 hr fuels remained significantly greater in $M$ units than in $\mathrm{C}$ units. In year 12, all fuel variables did not differ between $\mathrm{M}$ and $\mathrm{C}$ units except that $\mathrm{M}$ units had a significantly thinner litter layer than $\mathrm{C}$ units.

\section{Burn-Only Treatment (B)}

Basal area of overstory trees declined gradually in B units (Figure 3) from $26.5 \mathrm{~m}^{2}$ $\mathrm{ha}^{-1}$ prior to the first burn to $25.2 \mathrm{~m}^{2} \mathrm{ha}^{-1}$ in year 12 (Table 1). Even though basal area was declining in $\mathrm{B}$ treatment units and increasing in $\mathrm{C}$ units, the difference did not become significant until year 9, just prior to the third prescribed burn. After that year, basal area was always lower in $\mathrm{B}$ units than in $\mathrm{C}$ or $\mathrm{M}$ units and higher than in MB units. Density of overstory trees followed the same pattern. Numbers of overstory trees did not differ significantly in B, C, and $\mathrm{M}$ units until year 9 (Table 1). Beginning that year, there were fewer overstory stems in $\mathrm{B}$ units than in $\mathrm{M}$ or $\mathrm{C}$ units and greater than in MB units.

Numbers of stems in the shrub layer counted in B treatment units changed rapidly over the course of the study (Table 2). Shrub density was significantly lower in B units than in $\mathrm{C}$ units the first year after each prescribed fire (years 1, 5, and 10). However, density was either the same or significantly higher in B units than in $\mathrm{C}$ units if time since burning was more than one year (years 3, 9, 11, and 12). Shrub cover was significantly lower in B units than in $\mathrm{C}$ units every year except the pretreatment year and the sixth year after the second burn (year 9).

Density of tree reproduction, both in the oak- and the all-species categories, was significantly higher in $\mathrm{B}$ units than in $\mathrm{C}$ units almost every year (Table 3). Exceptions were during the pretreatment year and for oaks in years 1 and 9. During some years, the number of regeneration-sized trees in the all-species group was two to three times greater in B units than in $\mathrm{C}$ units (years 1, 3, 10, 11, and 12).

Cover of plants $\leq 1.4 \mathrm{~m}$ tall was largely unaffected by the B treatment (Table 4), with the exception of cover by trees in this size class. Cover of forbs, grasses, and shrubs was not significantly different in $\mathrm{B}$ units than in $\mathrm{C}$ units during any year. Cover of regenerating trees was not significantly different in $\mathrm{B}$ units than in $\mathrm{C}$ units until the first year after the second prescribed fire (year 5). Cover remained significantly higher through the remainder of the study except during the first year after the third burn (year 10).

The burn-only treatment (B) had little impact on the mass of $1 \mathrm{hr}, 10 \mathrm{hr}$, and $100 \mathrm{hr}$ fuels during this study (Table 5). Weights of these fuels did not differ significantly from those in $\mathrm{C}$ treatment units except that the mass of $1 \mathrm{hr}$ fuels was lower in B units than in $\mathrm{C}$ units the first year after the second burn (year 5). Litter depth was shallower in B units than in $\mathrm{C}$ units in most measured years. Duff depth was not different between $\mathrm{B}$ and $\mathrm{C}$ units until year 11, the second year after the third burn. Duff was significantly thinner on B units than on $\mathrm{C}$ units in years 11 and 12 .

\section{Mechanical and Burn Treatment (MB)}

Basal area of overstory trees was significantly lower in MB units (Figure 4) than in all other treatment units the first year after treatment installation (Table 1). Basal area reduced from $23.8 \mathrm{~m}^{2} \mathrm{ha}^{-1}$ to $21.0 \mathrm{~m}^{2} \mathrm{ha}^{-1}$ during the first year after the first treatment and continued 
Table 5. Mean loading of woody fuels and forest floor depth by treatment and year, Green River Game Land, Polk County, North Carolina, USA.

\begin{tabular}{|c|c|c|c|c|c|}
\hline & $\begin{array}{c}1 \mathrm{hr} \\
\left(\mathrm{Mg} \mathrm{ha}^{-1}\right)\end{array}$ & $\begin{array}{c}10 \text { hr } \\
\left(\mathrm{Mg} \mathrm{ha}^{-1}\right)\end{array}$ & $\begin{array}{c}100 \mathrm{hr}^{-1} \\
\left(\mathrm{Mg} \mathrm{ha}^{-1}\right)\end{array}$ & $\begin{array}{l}\text { Litter } \\
(\mathbf{c m})\end{array}$ & $\begin{array}{l}\text { Duff } \\
(\mathrm{cm})\end{array}$ \\
\hline \multicolumn{6}{|c|}{$\overline{\text { Pretreatment }}$} \\
\hline $\mathrm{C}$ & 0.3 & 1.8 & 5.2 & 5.1 & 3.6 \\
\hline $\mathrm{B}$ & 0.4 & 2.0 & 4.5 & 4.8 & 4.6 \\
\hline M & 0.3 & 1.8 & 3.4 & 4.6 & 4.1 \\
\hline MB & 0.4 & 1.8 & 4.7 & 5.1 & 4.6 \\
\hline \multicolumn{6}{|c|}{ Year 1 (1 growing season after first burn and mechanical treatments) } \\
\hline $\mathrm{C}$ & $0.5 \mathrm{a}^{1}$ & $1.8 \mathrm{ab}$ & $3.8 \mathrm{a}$ & $4.3 \mathrm{~b}$ & 3.6 \\
\hline B & $0.5 \mathrm{a}$ & $2.0 \mathrm{ab}$ & $4.5 \mathrm{ab}$ & $1.0 \mathrm{a}$ & 3.6 \\
\hline M & $0.8 \mathrm{~b}$ & $3.2 \mathrm{~b}$ & $6.3 \mathrm{c}$ & $5.6 \mathrm{c}$ & 5.3 \\
\hline MB & $0.4 \mathrm{a}$ & $1.7 \mathrm{a}$ & $5.4 \mathrm{bc}$ & $0.5 \mathrm{a}$ & 3.0 \\
\hline \multicolumn{6}{|l|}{ Year 3} \\
\hline $\mathrm{C}$ & $0.6 \mathrm{a}$ & $1.3 \mathrm{a}$ & $4.0 \mathrm{a}$ & $4.6 \mathrm{~b}$ & $3.0 \mathrm{a}$ \\
\hline $\mathrm{B}$ & $0.6 \mathrm{a}$ & $1.6 \mathrm{ab}$ & $4.7 \mathrm{a}$ & $4.1 \mathrm{ab}$ & $2.8 \mathrm{a}$ \\
\hline M & $0.8 \mathrm{~b}$ & $2.4 \mathrm{c}$ & $6.5 \mathrm{~b}$ & $5.8 \mathrm{c}$ & $4.1 \mathrm{~b}$ \\
\hline MB & $0.6 \mathrm{a}$ & $1.9 \mathrm{~b}$ & $6.5 \mathrm{~b}$ & $3.3 \mathrm{a}$ & $3.0 \mathrm{a}$ \\
\hline \multicolumn{6}{|c|}{ Year 5 (1 growing season after second burn) } \\
\hline $\mathrm{C}$ & $1.1 \mathrm{c}$ & 2.1 & $5.4 \mathrm{a}$ & $5.3 \mathrm{~b}$ & $3.0 \mathrm{~b}$ \\
\hline B & $0.9 \mathrm{~b}$ & 2.1 & $5.6 \mathrm{a}$ & $5.3 \mathrm{~b}$ & $3.0 \mathrm{~b}$ \\
\hline M & $1.1 \mathrm{c}$ & 2.4 & $7.6 \mathrm{~b}$ & $6.1 \mathrm{~b}$ & $2.8 \mathrm{~b}$ \\
\hline MB & $0.5 \mathrm{a}$ & 1.8 & $7.4 \mathrm{~b}$ & $0.5 \mathrm{a}$ & $1.3 \mathrm{a}$ \\
\hline \multicolumn{6}{|l|}{ Year 92 } \\
\hline $\mathrm{C}$ & & & & & \\
\hline $\mathrm{B}$ & 0.6 & 2.7 & 6.5 & 6.4 & 3.6 \\
\hline \multicolumn{6}{|l|}{ M } \\
\hline MB & 0.7 & 3.1 & 6.5 & 7.1 & 4.1 \\
\hline \multirow{2}{*}{\multicolumn{6}{|c|}{$\begin{array}{l}\text { Year } 10^{2} \text { (1 growing season after third burn and second mechanical treatments) } \\
{ }_{C}\end{array}$}} \\
\hline & & & & & \\
\hline $\mathrm{B}$ & 0.8 & 2.7 & 7.4 & 2.3 & 3.0 \\
\hline \multicolumn{6}{|l|}{ M } \\
\hline $\mathrm{MB}$ & 0.6 & 2.4 & 7.6 & 1.8 & 2.3 \\
\hline \multicolumn{6}{|l|}{ Year 11} \\
\hline $\mathrm{C}$ & 1.0 & 2.8 & 6.7 & $7.1 \mathrm{~b}$ & $4.1 \mathrm{~b}$ \\
\hline $\mathrm{B}$ & 0.9 & 3.0 & 7.4 & $4.6 \mathrm{a}$ & $3.0 \mathrm{a}$ \\
\hline M & 1.3 & 4.0 & 7.4 & $7.4 \mathrm{~b}$ & $4.6 \mathrm{~b}$ \\
\hline $\mathrm{MB}$ & 0.8 & 2.7 & 7.4 & $4.1 \mathrm{a}$ & $1.8 \mathrm{a}$ \\
\hline \multicolumn{6}{|l|}{ Year 12} \\
\hline $\mathrm{C}$ & 0.8 & 2.6 & 5.2 & $6.9 c$ & $3.6 \mathrm{c}$ \\
\hline B & 0.9 & 2.8 & 6.7 & $5.6 \mathrm{a}$ & $2.5 \mathrm{~b}$ \\
\hline $\mathrm{M}$ & 1.2 & 3.6 & 7.0 & $6.6 \mathrm{~b}$ & $3.8 \mathrm{c}$ \\
\hline $\mathrm{MB}$ & 0.9 & 3.0 & 7.4 & $5.1 \mathrm{a}$ & $1.8 \mathrm{a}$ \\
\hline
\end{tabular}

\footnotetext{
${ }^{1}$ Means followed by the same letter within a column and year are not significantly different at the Bonferroni adjusted level $\alpha=0.00625$ (overall $\alpha=0.05$ ). The absence of letters indicates that there were no significant differences within that column and year.

${ }^{2}$ Fuels data were not collected in $\mathrm{C}$ and $\mathrm{M}$ treatment units in year 9 and year 10.
} 


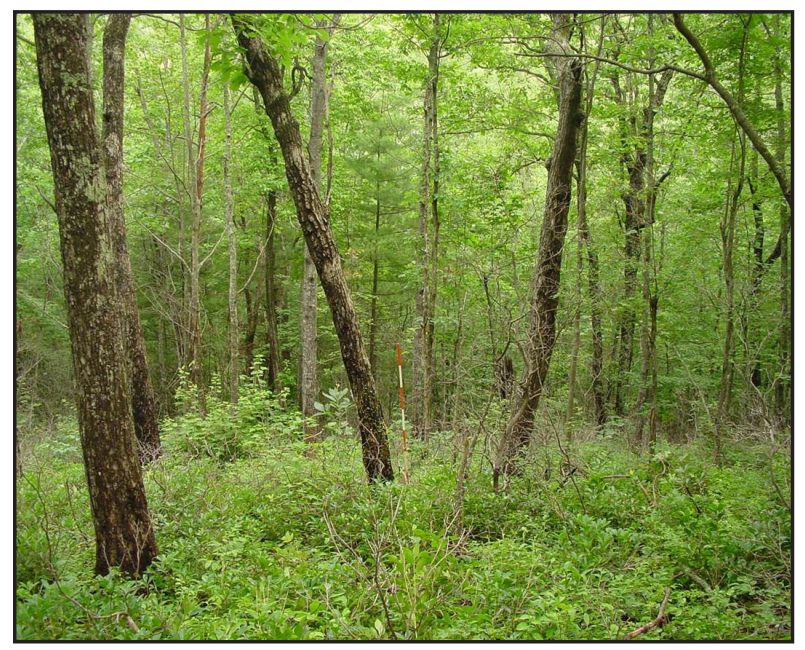

Figure 3. The burn-only treatment top-killed small trees and shrubs, which resprouted prolifically. Overstory density was reduced by burning but not enough to reach restoration goals.

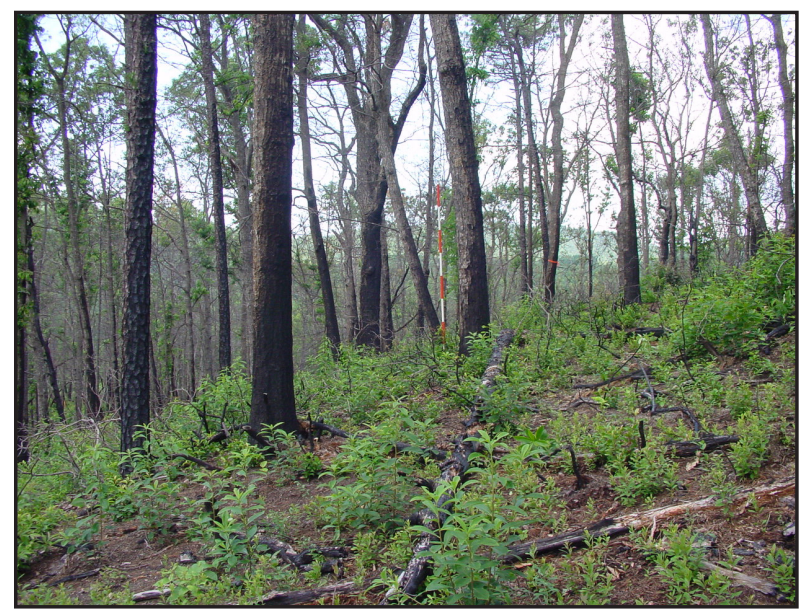

Figure 4. The combination of mechanical and burning treatments killed small trees and shrubs that resprouted after every fire. Overstory density was reduced by $37 \%$ over the 12 -year study.

to decrease almost every year. By year 12, the basal area in MB units had reduced by $37 \%$ to $14.9 \mathrm{~m}^{2} \mathrm{ha}^{-1}$. Overstory tree density was significantly lower in $\mathrm{MB}$ units than in all other treatment units for all years except the pretreatment year and the year following the first prescribed burn. There were no significant differences among any of the treatments during those years.
Density of stems in the shrub layer was significantly higher in $\mathrm{MB}$ units than in all other treatment units during every year except during the first year after the first fire and the first year after the third fire. During those years, shrub layer density was significantly lower in $\mathrm{MB}$ units than in $\mathrm{C}$ units. Cover in $\mathrm{MB}$ units was significantly lower than in $\mathrm{C}$ units for every year except year 9, the sixth year after the second burn.

Density of tree reproduction was significantly higher in burned treatment units (MB and B) than in unburned units for both oakand the all-species categories (Table 3 ) for all years except for oaks in year 9. In most years, there was no significant difference in the number of regeneration-sized trees between $\mathrm{B}$ and MB units.

Total forest floor cover in MB treatment units was not significantly different in $\mathrm{MB}$ units than in all other treatment units until year 9. In years 9 through 12 , total forest floor cover was significantly higher in MB units than in all other treatment units. Significantly higher cover in MB units was detected for forbs each year after the second burn (year 5) except during year 10, the first year after the third burn. Tree cover was significantly higher in MB plots than in all other treatment units each year after the first treatment (year 1) except in years 5 and 9, when tree cover was not significantly different between $\mathrm{B}$ and $\mathrm{MB}$ units.

The MB treatment units tended to have lower loading of $1 \mathrm{hr}$ and $10 \mathrm{hr}$ fuels than did $\mathrm{M}$ units, but there were few differences in loadings of these fuels between $\mathrm{M}$ units and $\mathrm{C}$ or B units. (Table 5). Mass of $100 \mathrm{hr}$ fuels was significantly lower in $\mathrm{MB}$ units than in $\mathrm{C}$ units in years 1,3 , and 5 , but there were no significant differences in other years. Litter depth was less in MB units than in unburned units each year after the first treatment. However, it was not significantly different than in $B$ units except in year 5, when it was much lower. Duff depth was not different in MB units than in $\mathrm{C}$ units until after the second burn 
(year 5). After that, duff was thinner in MB units than in unburned units and became thinner than in all other treatment units in year 12.

\section{DISCUSSION}

\section{Mechanical Treatment (M)}

For the restoration objective, the $\mathrm{M}$ treatment failed to create an open overstory and a diverse forest floor of graminoids and forbs, two of the three targeted woodland characteristics. While the dense shrub layer was reduced, repeated application of this treatment will be necessary to keep reproduction-chiefly that of ericaceous resprouts and undesirable mesophytic hardwoods such as yellow-poplar (Liriodendron tulipifera L.), birches (Betula spp. L.), and maples (Acer spp. L.)-from growing into this size class. Graminoids and forbs are unlikely to establish and persist in an environment in which the overstory remains intact, midstory competition is only temporarily reduced, and litter and duff depth increase (Keyser et al. 2012). Although alternative mechanical treatments, such as mastication, have proven effective at restoring forest structure in other regions (Kreye et al. 2014, Stottlemyer et al. 2015), we conclude that our stand structure goals will be difficult to attain solely via chainsaw felling of shrubs and small trees. The efficacy of $\mathrm{M}$ could perhaps be increased with targeted herbicide application to control mesophytic resprouts, as has been done in other forest communities (Kochenderfer et al. 2012). However, managers would incur this additional cost on top of an already expensive treatment and the overstory would remain dense. A less costly alternative could be thinning to a larger diameter limit, thus removing some midstory and overstory trees to open the canopy. This method was used at the Ohio Hills site of the FFS with results similar to those of the B treatment in this study (Waldrop et al. 2008).

Oak reproduction increased slightly, but this did not occur until after the second $M$ treatment. Almost all new reproduction was of sprout origin, which suggests that the requisite conditions for acorn germination and seedling establishment are not created by the $M$ treatment. The entire regeneration process, from acorn to sapling, can take up to $25 \mathrm{yr}$ (Carvell and Tryon 1961, Clark and Watt 1971, Sander 1972). Along with an abundance of acorns (which we did not quantify), successful oak regeneration from seed requires seedbed preparation, competition control, abundant sunlight, and a number of other factors. Both litter depth and duff depth should be reduced and sunlight should be increased. Historically, these could have been accomplished by periodic burning (Brose et al. 2014); thus M, by itself, was not an effective fire surrogate for an oak regeneration objective. In the absence of fire, competition from the established overstory and the resprouting shrubby midstory makes it unlikely that many of the oak resprouts will grow into larger size classes (Beck and Hooper 1986, Waldrop et al. 2008). Mechanical treatment alone does not appear to be a viable option for promoting oak regeneration. Without sufficient oak reproduction, overstory oaks will likely be replaced by non-oak species when they die (Brose et al. 2014).

Fuels decreased by reducing the shrub layer but at the expense of increased fine fuels. Until these fuels decompose, they may make the stand more susceptible to wildfire. Predictive models suggest that these wildfires would be very intense and have rapid spread rates (Waldrop et al. 2010). If such fires were to occur, desirable levels of overstory mortality, herbaceous layer establishment, and oak regeneration could result (Hagan et al. 2015). However, relying on a wildfire to meet restoration objectives is not recommended.

\section{Burn-Only Treatment (B)}

Burning reduced overstory density only slightly, although delayed mortality of overstory trees may occur in future years, especially if periodic burning continues. The shrub 
layer was decreased but woody sprouts dominated the forest floor. Burning alone may eventually create a woodland condition, but another fire regime may be necessary. Currently, nearly all prescribed burns in the southern Appalachian Mountains are conducted during the dormant season (Brose et al. 2014). Growing-season fires, which not only burn at a warmer time of year but also consume vegetation when a greater portion of their carbohydrates are stored aboveground, may be effective at eliminating unwanted hardwoods and encouraging graminoids and forbs (Hutchinson et al. 2005, Knapp et al. 2009). However, evidence from other regions in the US suggests that growing-season burns must be repeated for many consecutive years before undesirable hardwood resprouts can be eliminated. For example, in loblolly pine (Pinus taeda L.) forests of the coastal plain of South Carolina, annual growing season burns were conducted for $20 \mathrm{yr}$ without interruption before graminoids and forbs completely replaced hardwoods such as sweetgum (Liquidambar styraciflua L.) in the understory. Periodic growing-season fires (every 2 yr) were markedly less effective, since the fire-free intervals gave the established hardwoods opportunities to recover (Waldrop et al. 1992). A similar pattern may hold true in the southern Appalachians, but it remains to be seen if land managers would be receptive to using growing season burns in an environment where burning windows are short and extreme topography makes fire behavior difficult to predict. However, if desirable stand conditions could be achieved with repeated growing-season burns, this forest structure could potentially be maintained by periodic low-intensity surface fires, including dormant-season burns, like those that historically occurred (Brose et al. 2001). Herbicides could also be used to control undesirable resprouts.

In the absence of fire, unfavorable seedbed conditions and intense competition can make it very difficult for oak seedlings to establish on mesic sites (Brose et al. 2014). In this study, burn units consisted of sites ranging from mesic to xeric. Much of the burn unit was dry where competition from other hardwoods with oaks is not a problem. Oak reproduction increased after the first burn and remained above $\mathrm{C}$ levels for the remainder of the study period. The majority of new reproduction was sprouts, which should compete favorably with the other resprouting hardwoods.

Live fuel loads decreased due to the removal of the shrubby midstory layer. Fine fuels increased but probably are not highly flammable since they were mostly hardwood leaves and twigs that were partially consumed by the fire before falling to the ground. Such fuels tend to lie flat, which decreases their potential for burning, especially in protected sites on which fire behavior is constrained by high humidity. Since periodic fires in the B treatment reduce the rate of fuel accumulation, relative to $\mathrm{M}$, the potential for high-intensity fire is reduced compared to that treatment (Waldrop et al. 2010). Consumption of $10 \mathrm{hr}$ fuels by fire was offset by new additions from top-killed shrubs and saplings, which explains why there was little to no reduction in fuel volumes under this treatment scenario.

\section{Mechanical and Burn Treatment (MB)}

The failure of the $\mathrm{M}$ and $\mathrm{B}$ treatments to achieve stand structure goals suggests that a more aggressive approach may be necessary. Fuel management strategies that combine both fire and mechanical treatment have proven effective at restoring forest structure in other regions, particularly in areas in which high levels of fuel accumulation make the B treatment impractical (e.g., the wildland-urban interface; Albrecht et al. 2006, Glitzenstein et al. 2006). While overstory trees were not targeted for removal with $\mathrm{MB}$, this treatment contributed to substantial reductions in overstory basal area over time. The first and second fires in these treatment units were more intense than those of B units, resulting in greater initial and delayed mortality. This in turn allowed more 
sunlight to reach the forest floor. The shrub layer was decreased but woody sprouts dominated the understory. However, the combination of increased sunlight, decreased competition, and decreased litter and duff depth may be responsible for the more abundant herbaceous layer. Increased light availability is particularly important for graminoids, which typically require $<50 \%$ canopy coverage in order to proliferate (Starver et al. 2011). Reductions in basal area due to midstory removal and delayed overstory mortality signal a slow shift toward a desirable forest structure and will further facilitate graminoids and herbs if hardwood sprouts can be controlled. But the control of these hardwood sprouts probably cannot be achieved without the application of growing-season burns or herbicide, as described above.

Mechanical treatments to reduce basal area, followed by burning, have proven effective for promoting oak reproduction in the central Appalachians and adjacent Piedmont (Iverson et al. 2008, Stottlemyer et al. 2015). However, such treatments often involve twostep overstory removal (e.g., shelterwood systems), followed by a release burn (Brose and Van Lear 1998). Such a strategy provides the requisite conditions for oak seedling establishment, and gives these young trees a competitive advantage over their mesophytic hardwood competitors. In this study, oak reproduction was increased but almost all new reproduction was of sprout origin. Also problematic was the fact that litter and duff thickness remained relatively high, despite temporary post-treatment reductions. Additional reductions in basal area-perhaps overstory thinning - in concert with burning may be necessary to encourage oak regeneration from seed.

Fuels decreased by reducing the shrub layer. As was the case with B, the fine fuels were comprised primarily of leaves that are not highly flammable. However, there was a greater proportion of fine live fuels (graminoids and herbs) relative to the other treat- ments. Reductions in basal area increased exposure, which, combined with a more flammable fuel bed, may facilitate fire in MB stands. However, predicted and observed fire intensity in the MB treatment was low relative to the other treatments (Waldrop et al. 2010).

\section{CONCLUSIONS}

A survey of Appalachian fire managers indicated a need for much research, particularly on reaching restoration goals, improving oak regeneration, and reducing fuels. The Appalachian site of the National Fire and Fire Surrogate Study provides some information for each of these research needs. There, fuel reduction treatments were designed to restore hardwood sites, with dense shrub layers, to open woodlands by restoring function (B), structure (M), or a combination of both (MB). Treatment units were established to include sites of varying quality. However, our results cannot represent every combination of slope, aspect, soil moisture, and other variables found in the southern Appalachian Mountains.

After three fires and two mechanical treatments, stand structure was not altered enough by any of these treatments to produce the desired community. Each fuel reduction treatment changed stand structure differently, resulting in different degrees of success. The M treatments reduced the shrub layer, but did not reduce overstory cover or improve species richness along the forest floor. The canopy was reduced slightly with the B treatments and the shrub layer was removed. However, numerous sprouts of trees and shrubs probably out-competed any grasses and forbs that may have occurred on the forest floor. The MB treatment produced a stand structure most like that of open woodlands by killing a large portion of overstory trees and top-killing almost every stem in the shrub layer. However, tree and shrub sprouts were numerous and may have prevented an increase in herbaceous regeneration. The $\mathrm{B}$ and $\mathrm{MB}$ treatments may eventually produce the desired stand condition 
but many repeated fires may be needed. Burning more frequently or in a different season may speed the process. Combining fire with herbicides and mastication may eventually kill all sprouts of trees and shrubs and allow regeneration of a rich herbaceous forest floor. However, information is lacking.

Numbers of regenerating oak stems significantly increased on treatment units immediately after burning ( $\mathrm{B}$ and $\mathrm{MB}$ ) and remained higher than on $\mathrm{C}$ or $\mathrm{M}$ treatment units throughout the study. The majority of oak reproduction was observed to be from multiple sprouts from a stem that was top-killed by fire or the mechanical treatment. Gains in oak reproduction numbers in $\mathrm{B}$ and $\mathrm{MB}$ treatment units indicate that there were no negative short-term impacts to oak. However, those gains may be only short term as sprouts self-thin or as they are killed by repeated burning as open woodland condition is created.

In this study, fuel reduction treatments were designed to reduce forest floor fuels, down woody fuels, and vertical fuels. Each treatment reduced one or more of these types of fuel. The $\mathrm{M}$ treatment eliminated the vertical fuel component but added litter and woody fuels, which could cause a wildfire to be more intense for up to five years. Prescribed burning alone or in combination with the mechanical treatment consumed the litter layer. However, this effect lasted less than three years, emphasizing the need for frequent burning to maintain protection from wildfire. Fine woody fuels were increased by all treatments. This effect is common among studies of prescribed burning as small trees and shrubs are top-killed and the burned limbs and stems fall to the ground. Because these limbs and stems have been partially burned, they probably would not be consumed in a subsequent wildfire. All active treatments decreased the shrub layer, which then led to prolific sprouting of trees and shrubs. Vegetation of this size class is com- mon throughout much of the southern Appalachian Mountains but is not found throughout. Fuel reduction may not be as critical where a dense layer of ericaceous shrubs does not exist. There, burning is used for other purposes and would produce different results.

While it may be possible to obtain each of the three objectives of this study (open woodland, oak reproduction, and fuel reduction) simultaneously, it will be a challenge to reduce hardwood and shrub sprouting without also impeding oak regeneration. Continued burning and periodic re-measurement of treatment units in this study is necessary. Managers may need to decide between open woodland with a diminishing overstory over time through frequent burning or a more woody community that has ingrowth to the overstory through infrequent burning.

This study represents a considerable effort over 12 years to reach management objectives for restoration, oak regeneration, and fuel reduction. The study provides a better understanding of the effort, time, and expense required to convert dense Appalachian hardwood forests to open woodlands after three prescribed fires and two mechanical treatments. Our most intense treatment, MB, approaches the desired structure but, as found in the southern Coastal Plain (Waldrop et al. 1992), many additional burns are needed to eliminate sprouting, perhaps as often as every two years. Fuel reduction objectives will be met by $\mathrm{B}$ or $\mathrm{MB}$, especially as restoration objectives are met. Both restoration and fuel objectives may require that burning be conducted more frequently, in a different season, or in combination with other treatments. Herbicides or mastication could speed the process of restoration. The objective of increasing oak reproduction was met by all active treatments. Managers should consider the advantages and disadvantages shown for each of these treatments when trying to meet management goals. 


\section{ACKNOWLEDGEMENTS}

This research was supported by the Joint Fire Science Program. Original funding to establish the study site was from the US Forest Service National Fire Plan. The North Carolina Wildlife Resources Commission allowed us to use their land and installed and maintained treatments. Numerous employees and students established study plots and measured vegetation and fuels over the years. We are grateful to each, and special thanks go to G. Chapman, E. Gambrell, H. Mohr, R. Phillips, and M. Smith.

\section{LITERATURE CITED}

Albrecht, M.A., and B.C. McCarthy. 2006. Effects of prescribed fire and thinning on tree recruitment patterns in central hardwood forests. Forest Ecology and Management 226: 88103. doi: 10.1016/j.foreco.2005.12.061

Beck, D.E., and R.M. Hooper. 1986. Development of a southern Appalachian hardwood stand after clearcutting. Southern Journal of Applied Forestry 10: 168-172.

Bland J.M., and D.G. Altman. 1995. Multiple significance tests: the Bonferroni method. British Medical Journal 310: 170. doi: 10.1136/bmj.310.6973.170

Boerner, R.E.J., T.A. Coates, D.A. Yaussy, and T.A. Waldrop. 2008. Assessing ecosystem restoration alternatives in Eastern deciduous forests: the view from belowground. Restoration Ecology 16: 425-434. doi: 10.1111/j.1526-100X.2007.00312.x

Brose, P., D.C. Dey, and T.A. Waldrop. 2014. The fire-oak literature of eastern North America: synthesis and guidelines. USDA Forest Service General Technical Report SRS-135, Southern Research Station, Asheville, North Carolina, USA.

Brose, P.H., T.M. Schuler, D.H. Van Lear, and J. Berst. 2001. Bringing fire back: the changing regimes of the Appalachian mixed oak forest. Journal of Forestry 99: 30-35.

Brose, P.H., F. Tainter, and T.A. Waldrop. 2002. Regeneration history of Table Mountain/pitch pine stands in two locations in the southern Appalachians. Pages 296-301 in: K. Outcalt, editor. Proceedings of the Eleventh Biennial Southern Silvicultural Research Conference. USDA Forest Service General Technical Report SRS-48, Southern Research Station, Asheville, North Carolina, USA.

Brose, P.H., and D.H. Van Lear. 1998. Responses of hardwood advance regeneration to seasonal prescribed fires in oak dominated shelterwood stands. Canadian Journal of Forest Research 28: 331-339. doi: 10.1139/x97-218

Brown, J.K. 1974. Handbook for inventorying downed woody material. USDA Forest Service General Technical Report INT-16, Ogden, Utah, USA.

Buckner, E. 1983. Archaeological and historical basis for forest succession in eastern North America. Pages 182-187. Proceedings of the 1982 Society of American Foresters national convention. Publication 83-04, Society of American Foresters, Bethesda, Maryland, USA.

Carvell, K.L., and E.H. Tryon. 1961. The effect of environmental factors on the abundance of oak regeneration beneath mature oak stands. Forest Science 7: 98-105.

Clark, F.B., and R.F Watt. 1971. Silvicultural methods for regenerating oaks. Pages 34-73 in: D.E. White and B.A. Roach, editors. Oak symposium proceedings. USDA Forest Service, Northeastern Research Station, Upper Darby, Pennsylvania, USA.

Delcourt, H.R., and P.A. Delcourt. 1997. Pre-Columbian Native American use of fire on southern Appalachian landscapes. Conservation Biology 11: 1010-1014. doi: 10.1046/j.1523-1739. 1997.96338.x 
Denevan, W.M. 1992. The pristine myth: the landscape of the Americas in 1492. Annals of the Association of American Geographers 82: 369-385. doi: 10.1111/j.1467-8306.1992. tb01965.x

Dobyns, H.F. 1983. Their numbers became thinned: Native American population dynamics in eastern North America. University of Tennessee Press, Knoxville, USA.

Hagan, D.L., T.A. Waldrop, M. Reilly, and T.M. Shearman. 2015. Impacts of repeated wildfire on long-unburned Appalachian plant communities of the southern Appalachian Mountains. International Journal of Wildland Fire 24: 911-920. doi: 10.1071/wf14143

Glitzenstein, J.S., D.R. Streng, G.L. Achtemeier, L.P. Naeher, and D.D. Wade. 2006. Fuels and fire behavior in chipped and unchipped plots: implications for land management near the wildland/urban interface. Forest Ecology and Management 236: 18-29. doi: 10.1016/j. foreco.2006.06.002

Hutchinson, T. 2006. Fire and the herbaceous layer of Eastern oak forests. Pages 136-151 in: M.B. Dickinson, editor. Fire in Eastern oak forests: delivering science to land managers, proceedings of a conference. USDA Forest Service General Technical Report NRS-P-1, Northern Research Station, Newtown Square, Pennsylvania, USA.

Hutchinson, T.F., R.E.J. Boerner, S. Sutherland, E.K. Sutherland, M. Ortt, and L.R. Iverson. 2005. Prescribed fire effects on the herbaceous layer of mixed-oak forests. Canadian Journal of Forest Research 35: 877-890. doi: 10.1139/x04-189

Iverson, L.R., T.F. Hutchinson, A.M. Prasad, and M.P. Peters. 2008. Thinning, fire, and oak regeneration across a heterogeneous landscape in the eastern US: 7-year results. Forest Ecology and Management 255: 3035-3050. doi: 10.1016/j.foreco.2007.09.088

Kabrick, J.M., D.C. Dey, C.O. Kinkead, B.O. Knapp, M. Leahy, M.G. Olson, M.C. Stambaugh, and A.P. Stevenson. 2014. Silvicultural considerations for managing fire-dependent oak woodland ecosystems. Pages 2-15 in: J.W. Groninger, E.J. Holzmueller, C.K. Nielson, and D.C. Dey, editors. Proceedings of the 19th Central Hardwood forest conference. USDA Forest Service General Technical Report NRS-P-142, Northern Research Station, Newtown Square, Pennsylvania, USA.

Keenan, S.C. 1998. Soil survey of Polk County, North Carolina. USDA Natural Resources Conservation Service, Washington, D.C., USA.

Keyser, T.L., T. Roof, J.L. Adams, D. Simon, and G. Warburton. 2012. Effects of prescribed fire on the buried seed bank in mixed-hardwood forests of the southern Appalachian Mountains. Southeastern Naturalist 11: 669-688. doi: 10.1656/058.011.0407

Kinkead, C.O., J.M. Kabrick, M.C. Stambaugh, and K.W. Grabner. 2013. Changes to oak woodland stand structure and ground flora composition caused by thinning and burning. Pages 373-383 in: G.W. Miller, T.M. Schuler, K.W. Gottschalk, J.R. Brooks, S.T. Grushecky, B.D. Spong, and J.S. Rentch, editors. Proceedings of the 18th Central Hardwood forest conference. USDA Forest Service General Technical Report NRS-P-117, Northern Research Station Newtown Square, Pennsylvania, USA.

Knapp, E.E., B.L. Estes, and C.N. Skinner. 2009. Ecological effects of prescribed fire season: a literature review and synthesis for managers. USDA Forest Service General Technical Report PSW-GTR-224, Pacific Southwest Research Station, Albany, California, USA.

Kochenderfer, J.D., J.N. Kochenderfer, and G.W Miller. 2012. Manual herbicide application methods for managing vegetation in Appalachian hardwood forests. USDA Forest Service General Technical Report NRS-96, Northern Research Station, Newtown Square, Pennsylvania, USA. 
Kreye, J.K., L.N. Kobziar, and J.M. Camp. 2014. Immediate and short-term response of understory fuels following mechanical mastication in a pine flatwoods site of Florida, USA. Forest Ecology and Management 313: 340-354. doi: 10.1016/j.foreco.2013.10.034

MacCleery, D. 1993. Understanding the role the human dimension has played in shaping America's forest and grassland landscapes. American Forests and Paper 23(1): 1-9.

McIver, J.D., J.K. Agee, J. Barbour, R.E.J. Boerner, C.B. Edminster, K.L. Erickson, K.L. Farris, C.J. Fettig, C.E. Fiedler, S. Haase, S.C. Hart, J.E. Keeley, E.E. Knapp, J.F. Lehmkuhl, J.J. Moghaddas, W. Otrosina, K.W. Outcalt, D.W. Schwilk, C.N. Skinner, T.A.Waldrop, C.P. Weatherspoon, D.A. Yaussy, A. Youngblood, and S. Zack. 2012a. Ecological effects of alternative fuel-reduction treatments: highlights of the National Fire and Fire Surrogate study (FFS). International Journal of Wildland Fire 21: 894-904.

McIver, J., K. Erickson, and A. Youngblood. 2012b. Principal short-term findings of the National Fire and Fire Surrogate study. USDA Forest Service General Technical Report PNWGTR-860, Pacific Northwest Research Station, Portland, Oregon, USA.

Nelson, P.W. 2005. The terrestrial natural communities of Missouri. Missouri Natural Areas Committee, Jefferson City, Missouri, USA.

Nuzzo, V.A. 1986. Extent and status of Midwest oak savanna: pre-settlement and 1985. Natural Areas Journal 6: 6-36.

Phillips, R J., T.A. Waldrop, and D.M. Simon. 2006. Assessment of the FARSITE model for predicting fire behavior in the southern Appalachian Mountains. Pages 521-525 in: K.S. Connor, editor. Proceedings of the 13th biennial Southern silvicultural research conference. USDA Forest Service General Technical Report SRS-92, Southern Research Station, Asheville, North Carolina, USA.

Pyne, S.J. 1997. Fire in America: a cultural history of wildland and rural fire. Second edition. University of Washington Press, Seattle, USA.

SAMAB [Southern Appalachian Man and Biosphere Cooperative]. 1996. The southern Appalachian assessment summary report. Southern Appalachian Man and Biosphere Cooperative, Knoxville, Tennessee, USA.

Sander, I.L. 1972. Size of oak advance reproduction: key to growth following harvest cutting. USDA Forest Service Research Paper NC-79, North Central Research Station, St. Paul, Minnesota, USA.

Stanturf, J.A., D.D. Wade, T.A. Waldrop, D.K. Kennard, and G.L. Achtemeier. 2002. Fire in Southern forest landscapes. Pages 607-630 in: D.M. Wear and J. Greis, editors. Southern forest resource assessment. USDA Forest Service General Technical Report SRS-53, Southern Research Station, Asheville, North Carolina, USA.

Starver, A.C., S. Archibald, and S.A. Levin. 2011. The global extent and determinants of savanna and forest as alternative biome states. Science 334: 230-232. doi: 10.1126/science. 1210465

Stottlemyer, A.D., T.A. Waldrop, and G.G. Wang. 2015. Prescribed burning and mastication effects on surface fuels in southern pine beetle-killed loblolly pine plantations. Ecological Engineering 81: 514-524. doi: 10.1016/j.ecoleng.2015.04.076

Taft, J.B. 2009. Effects of overstory stand density and fire on ground layer vegetation in oak woodland and savanna habitats. Pages 21-39 in: T.F. Hutchinson, editor. Proceedings of the 3rd fire in Eastern oak forests conference. USDA Forest Service General Technical Report NRS-P-46, Northern Research Station Newtown Square, Pennsylvania, USA. 
Van Lear, D.H., and T.A. Waldrop. 1989. History, use, and effects of fire in the southern Appalachians. USDA Forest Service General Technical Report SE-54, Southeastern Forest Experiment Station, Asheville, North Carolina, USA.

Waldrop, T.A., L. Brudnak, and S. Rideout-Hanzak. 2007. Fuels on disturbed and undisturbed sites in the southern Appalachian Mountains, USA. Canadian Journal of Forest Research 37: 1134-1141. doi: 10.1139/X06-302

Waldrop, T., R.J. Phillips, and D.M. Simon. 2010. Fuels and predicted fire behavior in the southern Appalachian Mountains after fire and fire surrogate treatments. Forest Science 56: 32-45.

Waldrop, T.A., D.L. White, and S.M. Jones. 1992. Fire regimes for pine-grassland communities in the southeastern United States. Forest Ecology and Management 47: 195-210. doi: 10.1016/0378-1127(92)90274-D

Waldrop, T.A., D.A. Yaussy, R.J. Phillips, T.F. Hutchinson, L. Brudnak, and R.E.J. Boerner. 2008. Fuel reduction treatments affect stand structure of hardwood forests in western North Carolina and southern Ohio, USA. Forest Ecology and Management 255: 3117-3129. doi: 10.1016/j.foreco.2007.11.010

Youngblood, A., K.L. Metlen, E.E. Knapp, K.W. Outcalt, S.L. Stephens, T.A. Waldrop, and D. Yaussy. 2005. Implementation of the fire and fire surrogate study - a national research effort to evaluate the consequences of fuel reduction treatment. Pages 315-321 in: C.E. Peterson and D.A. Maguire, editors. Balancing ecosystem values: innovative experiments for sustainable forestry - proceedings of a conference. USDA Forest Service General Technical Report PNW-GTR-635, Pacific Northwest Station, Portland, Oregon, USA. 